\title{
A CO-Tolerant Electrocatalyst Based on Platinum and Organic Metal Clusters for Reformate Fuel Cells
}

\author{
Eunjoo Yoo, ${ }^{\text {a }}$ Toshiki Kahara, ${ }^{\mathrm{b}}$ Chisato Ono, ${ }^{\mathrm{b}}$ Junji Nakamura, ${ }^{\mathrm{a}}$ and \\ Tatsuhiro Okada ${ }^{\mathrm{b}, *, \mathrm{z}}$
}

${ }^{a}$ Graduate School of Pure and Applied Science, University of Tsukuba, Tsukuba, Ibaraki 305-8573, Japan

${ }^{b}$ National Institute of Advanced Industrial Science and Technology, Ibaraki 305-8565, Japan

CO-tolerant anode catalysts for reformate-type polymer electrolyte fuel cells are proposed and evaluated in comparison with $\mathrm{Pt}-\mathrm{Ru}$ alloy catalysts. Composite catalysts were fabricated by mixing platinum precursor and organic metal clusters on carbon and then heat-treating in $\mathrm{Ar}$ atmosphere at $400-500^{\circ} \mathrm{C}$. CO tolerance tests were conducted in the electrochemical cell using a rotating disk electrode. Also, the anode half-cell and the single fuel cell performances were measured at $70^{\circ} \mathrm{C}$ with $\mathrm{H}_{2}$ containing various levels of $\mathrm{CO}$. Compared with commercial Pt-Ru/C catalysts, this class of anode catalysts proved to be promising as CO-tolerant anode catalysts.

(c) 2008 The Electrochemical Society. [DOI: 10.1149/1.2901153] All rights reserved.

Manuscript submitted December 26, 2007; revised manuscript received February 14, 2008.

Available electronically March 28, 2008.

Polymer electrolyte fuel cells (PEFCs) are considered as promising power sources for stationary and residential applications. ${ }^{1}$ For such systems, the city gas and methane is reformed into hydrogen and $\mathrm{CO}_{2}$ and then fed to PEFC. During the reforming process, $\mathrm{CO}$ emerges as an impurity and comes into the anode gas chamber. $\mathrm{CO}$ blocks the active sites of Pt electrocatalysts and causes serious degradation in the electrode performance of the fuel cell anode. ${ }^{2}$ It is thus necessary to develop CO-tolerant catalyst materials which can endure $\mathrm{CO}$ poisoning at a level of $100 \mathrm{ppm}$. CO-tolerant electrocatalysts have been prepared by combinations of Pt with less noble elements, such as ruthenium, tin, molybdenum, and other transition metals. ${ }^{3,4} \mathrm{Pt}-\mathrm{Ru}$ supported on carbon $(\mathrm{Pt}-\mathrm{Ru} / \mathrm{C})$ has been developed as one of the most promising electrocatalysts for applications as CO-tolerant anode materials in PEFCs. ${ }^{5,6}$ However, the cell voltage with $100 \mathrm{ppm} \mathrm{CO}$ compared to pure hydrogen obtained with $\mathrm{Pt}-\mathrm{Ru} / \mathrm{C}$ anode is still too far from that acceptable for practical applications. Dissolution of alloy elements during PEFC operation is another problem when degradation of PEFC becomes an issue. ${ }^{7}$

Okada et al. have reported that $\mathrm{Pt}-\mathrm{VO}($ salen $) / \mathrm{C}$ and $\mathrm{Pt}-$ $\mathrm{Ni}(\mathrm{mqph}) / \mathrm{C}$ revealed high $\mathrm{CO}$ tolerance compared with $\mathrm{Pt} / \mathrm{C}$ and $\mathrm{PtRu} / \mathrm{C}$ alloy catalysts. ${ }^{8-11}$ It is considered that anode catalysts consisting of Pt and organic metal complexes are expected to be good candidates as the CO-tolerant anode catalysts of PEFCs.

In this paper, composite electrocatalysts based on Pt and organic metal clusters are prepared and their $\mathrm{CO}$ tolerance in hydrogen oxidation reaction (HOR) is studied with a rotating disk electrode in a glass electrochemical cell. The gas-phase tests are performed using a membrane electrode assembly in a half-cell and a single fuel cell system. The metal complex used in this work is a hexanuclear cluster $\left[\mathrm{Ln}_{2} \mathrm{Cu}_{4}(\text { fsaaep })_{4}\left(\mathrm{NO}_{3}\right)_{6}\right]$, which has a unique structure in that the lanthanoid element $\mathrm{Ln}$ bridges two $\mathrm{CuN}_{2} \mathrm{O}_{2}$ chelate units, and two Lns are located on both sides of the double layer containing the four $\mathrm{Cu}$ chelates (Fig. 1). ${ }^{12}$ Because the structure contains four $\mathrm{CuN}_{2} \mathrm{O}_{2}$ units, it is strongly expected that $\mathrm{OH}$ (and $\mathrm{CO}$ ) species will interact with these metal chelates and show $\mathrm{CO}$ eliminating action when used as a co-catalyst with Pt. The interatomic distances between four $\mathrm{Cu}$ chelates is manipulated by selecting the lanthanoid elements.

\section{Experimental}

The compound $\left[\mathrm{Ln}_{2} \mathrm{Cu}_{4}(\text { fsaaep })_{4}\left(\mathrm{NO}_{3}\right)_{6}\right]$, abbreviated as $\left.\left[\mathrm{Ln}_{2} \mathrm{Cu}_{4} \text { (fsaep) }\right)_{4}\right]$, where fsaaep $=$ Schiff's base compound between 3 -formilsalicylic acid and 2-(2-aminoethyl)pyridine, was synthesized following the procedure reported by Kahn et al. ${ }^{12}$ As lantha-

\footnotetext{
* Electrochemical Society Active Member

${ }^{\text {z }}$ E-mail: okada.t@aist.go.jp
}

noid elements, lutetium (Lu), praseodymium (Pr), and gadolinium $(\mathrm{Gd})$ were incorporated by reacting the precursor compound $\mathrm{Cu}$ (fsaaep) $)_{2} \cdot 5 \mathrm{H}_{2} \mathrm{O}$ with $\mathrm{Lu}\left(\mathrm{CH}_{3} \mathrm{COO}\right)_{3} \cdot 4 \mathrm{H}_{2} \mathrm{O}$ and $\mathrm{Ln}\left(\mathrm{NO}_{3}\right)_{3}(\mathrm{Ln}$ $=\mathrm{Pr}, \mathrm{Gd})$ in acetonitrille at room temperature. ${ }^{12}$ Resulting green precipitates were collected and dried in a vacuum oven at $60^{\circ} \mathrm{C}$.

Composite catalysts of $20 \mathrm{wt} \% \mathrm{Pt}$ amount on carbon was prepared from a mixture of platinum precursor $\mathrm{Pt}\left(\mathrm{NH}_{3}\right)_{4} \mathrm{Cl}_{2} \cdot x \mathrm{H}_{2} \mathrm{O}$, organic metal complex $\left[\mathrm{Ln}_{2} \mathrm{Cu}_{4}(\text { fsaaep })_{4}\right]$, and the carbon black powder (Vulcan XC-72R) in 1:1:1.3 mass ratio. The powder was dispersed in ethanol, dried in air at $40^{\circ} \mathrm{C}$ for $60 \mathrm{~min}$, and then subjected to heat-treatment in $\mathrm{Ar}$ stream at $400-500^{\circ} \mathrm{C}$ for $2 \mathrm{~h}$ in a furnace.

HOR of electrocatalysts was tested using a rotating disk electrode (RDE) equipped with a three-electrode glass cell in $0.1 \mathrm{~mol} \mathrm{dm}{ }^{-3} \mathrm{HClO}_{4}$ at $25^{\circ} \mathrm{C}$ under the bubbling of pure hydrogen or a mixture of $1 \% \mathrm{CO}$ with $\mathrm{H}_{2}$. Catalysts were loaded on a glassy carbon disk electrode with a Pt amount of 2.5 $\times 10^{-2} \mathrm{mg}(\mathrm{Pt}) \mathrm{cm}^{-2}$ (apparent area) with diluted (1:50) 5\% Nafion solution (Aldrich). The working electrode was the catalystsupported glassy carbon disk, the counter electrode was the platinum plate, and reversible hydrogen electrode (RHE) was used as the reference electrode. Polarization curves were recorded at the scan rate of $5 \mathrm{mV} \mathrm{s}^{-1}$, and the current at $0.1 \mathrm{~V}$ vs RHE was sampled for evaluation of HOR current.

$\mathrm{CO}$ tolerance tests for anode catalysts in a gas phase were conducted with a homemade Teflon half-cell equipped with a platinum mesh counter electrode, RHE, and the working electrode in $1 \mathrm{~mol} \mathrm{dm}^{-3} \mathrm{HClO}_{4}{ }^{9}$ The catalyst powder $(30 \mathrm{mg}$ ) was mixed with $5 \mathrm{wt} \%$ Nafion solution (Aldrich) $(500 \mathrm{mg})$ and ethanol $(30 \mathrm{mg})$ to make a catalyst ink. This ink was pasted on a carbon paper (Toray TGP-H-090) that was wet-proof treated with poly(tetrafluoroethylene) $\left(3.3 \times 10^{-3} \mathrm{~g} \mathrm{~cm}^{-2}\right)$ to prepare the anode electrode. ${ }^{11}$ The amount of $\mathrm{Pt}$ in the mixed catalyst was $0.3-0.5 \mathrm{mg}(\mathrm{Pt}) \mathrm{cm}^{-2}$ for the apparent electrode area. The membrane electrode assemblies (MEAs) were prepared by hot-pressing the electrode on one side of a cleansed Nafion 115 membrane at $135^{\circ} \mathrm{C}$ and $10 \mathrm{MPa}$ for $3 \mathrm{~min}$, and this half-MEA served as the working electrode. The PEFC polarization experiment was carried out using a potentiostat (ALS model $701 \mathrm{~A}$ ), with the cell at $70^{\circ} \mathrm{C}$ under the flow of pure hydrogen or a mixture of $\mathrm{H}_{2}$ with 10,50 , or $100 \mathrm{ppm} \mathrm{CO}$ in the anode.

Catalyst samples were also evaluated with a single fuel cell mode with $4 \mathrm{~cm}^{2}$ MEA. The anode was loaded with $20 \% \mathrm{Pt}-$ $\left.\left[\mathrm{Ln}_{2} \mathrm{Cu}_{4} \text { (fsaaep) }\right)_{4}\right] / \mathrm{C}$ or $20 \% \mathrm{Pt}-10 \% \mathrm{Ru} / \mathrm{C}$ (Johnson Matthey) catalysts on wet-proofed carbon paper (Toray TGP-H-090), with a Pt amount of $3 \times 10^{-4} \mathrm{~g}(\mathrm{Pt}) \mathrm{cm}^{-2}$, and the cathode was loaded with $20 \% \mathrm{Pt} / \mathrm{C}$ on carbon paper $\left[1 \times 10^{-3} \mathrm{~g}(\mathrm{Pt}) \mathrm{cm}^{2}\right.$, ElectroChem $]$. MEA was prepared by hot-pressing the anode and the cathode 


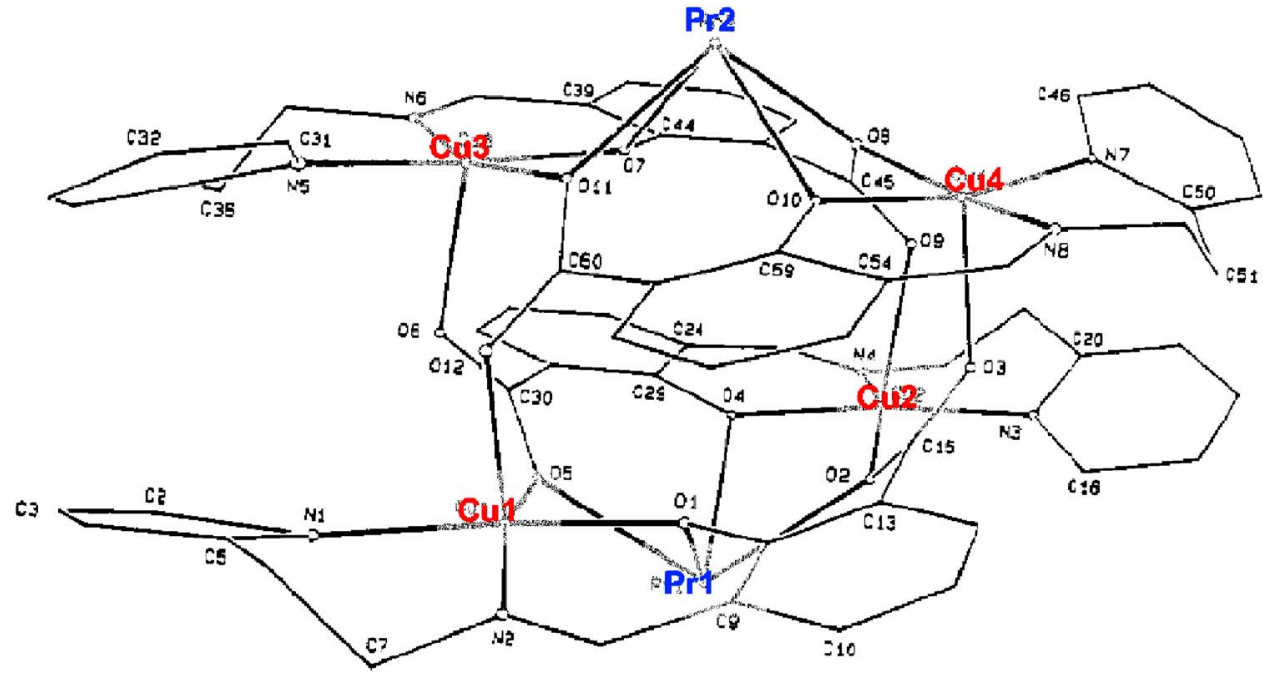

Figure 1. (Color online) View of hexanuclear cluster $\mathrm{Ln}_{2} \mathrm{Cu}_{4}(\text { fsaaep })_{4}\left(\mathrm{NO}_{3}\right)_{6} \cdot{ }^{12}$

catalyst-loaded carbon paper $\left(2 \times 2 \mathrm{~cm}^{2}\right)$ to each side of the Nafion 115 membrane at the pressure of $10 \mathrm{MPa}$ at $135^{\circ} \mathrm{C}$ for $3 \mathrm{~min}$.

\section{Results and Discussion}

Figure 2 shows polarization curves of $\mathrm{HOR}$ in $0.1 \mathrm{~mol} \mathrm{dm}^{-3}$ $\mathrm{HClO}_{4}$ at $25^{\circ} \mathrm{C}$, measured for RDE loaded with various catalysts. In a $\mathrm{H}_{2}$ saturated condition, $\mathrm{HOR}$ currents were around $1 \mathrm{~mA} \mathrm{~cm}^{-2}$ but declined when $1 \% \mathrm{CO}$ was added to $\mathrm{H}_{2}$. When $\mathrm{N}_{2}$ gas was bubbled in the solution, the current was almost zero, confirming that the observed polarization current was due to $\mathrm{H}_{2}$ oxidation. Comparing the $\mathrm{HOR}$ behavior without and with $\mathrm{CO}, \mathrm{Pt}-\left[\mathrm{Lu}_{2} \mathrm{Cu}_{4}(\text { fsaaep })_{4}\right] / \mathrm{C}$ appears to show a good $\mathrm{CO}$ tolerance as $\mathrm{Pt}-\mathrm{Ru} / \mathrm{C}$.

Table I summarizes the result of hydrogen oxidation current for various electrocatalysts at the same $\mathrm{Pt}$ amount. The mass activities
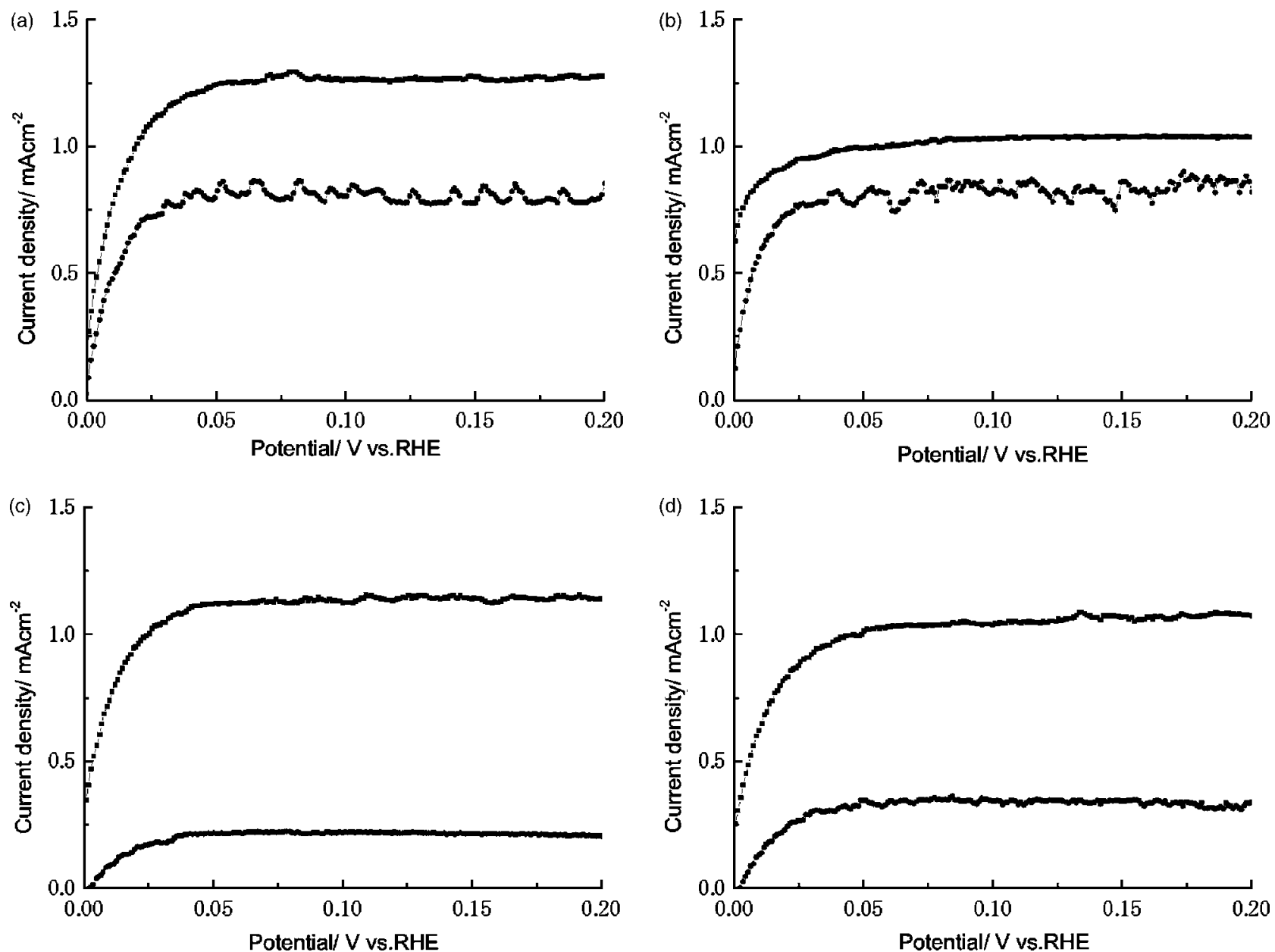

Figure 2. Polarization curves of HOR on RDE loaded with various catalysts, measured in $0.1 \mathrm{~mol} \mathrm{dm}^{-3} \mathrm{HClO}_{4}$ at $25^{\circ} \mathrm{C}$, where $\mathrm{H}_{2}$ gas is bubbled without and with 1\% CO: (a) Pt-Ru/C, (b) Pt-[ $\left[\mathrm{Lu}_{2} \mathrm{Cu}_{4}(\text { fsaaep })_{4}\right] / \mathrm{C}$, (c) Pt- $\left.\left[\mathrm{Pr}_{2} \mathrm{Cu}_{4} \text { (fsaaep) }\right)_{4}\right] / \mathrm{C}$, and (d) Pt- $\left[\mathrm{Gd}_{2} \mathrm{Cu}_{4}(\mathrm{fsaaep})_{4}\right] / \mathrm{C}$. Rotation speed $300 \mathrm{rpm}$, potential scan rate $5 \mathrm{mV} \mathrm{s}^{-1}$. 
Table I. Comparison of $\mathrm{H}_{2}$ oxidation current at $0.1 \mathrm{~V}$ vs RHE in $0.1 \mathrm{~mol} \mathrm{dm}{ }^{-3} \mathrm{HClO}_{4}$ saturated with $\mathrm{H}_{2}$ gas containing $1 \% \mathrm{CO}$, measured on RDE loaded with various electrocatalysts.

\begin{tabular}{|c|c|c|}
\hline & \multicolumn{2}{|c|}{$\begin{array}{l}\text { Mass activity }\left[\mathrm{mA} \mathrm{mg}\left(\mathrm{Pt}^{-1}\right)\right] \\
\text { current ratio }(\%)\end{array}$} \\
\hline & Pure $\mathrm{H}_{2}$ & $1 \% \mathrm{CO} / \mathrm{H}_{2}$ \\
\hline 20 wt $\% \mathrm{Pt}-10$ wt $\% \mathrm{Ru} / \mathrm{C}$ & $50.7(100)$ & $32.4(64)$ \\
\hline $20 \mathrm{wt} \% \mathrm{Pt}-\left[\mathrm{Lu}_{2} \mathrm{Cu}_{4}(\text { fsaaep })_{4}\right] / \mathrm{C}$ & $41.1(100)$ & $32.5(79)$ \\
\hline 20 wt $\% \mathrm{Pt}-\left[\mathrm{Pr}_{2} \mathrm{Cu}_{4}(\text { fsaaep })_{4}\right] / \mathrm{C}$ & $45.1(100)$ & $8.5(19)$ \\
\hline $20 \mathrm{wt} \% \mathrm{Pt}-\left[\mathrm{Gd}_{2} \mathrm{Cu}_{4}(\text { fsaeep })_{4}\right] / \mathrm{C}$ & $40.8(100)$ & $14.1(35)$ \\
\hline
\end{tabular}

in $\mathrm{H}_{2}$ gas were $50.7,41.1,45.1$, and $40.8 \mathrm{~mA} \mathrm{mg}(\mathrm{Pt})^{-1}$ for $\mathrm{Pt}-\mathrm{Ru} / \mathrm{C}, \mathrm{Pt}-\left[\mathrm{Lu}_{2} \mathrm{Cu}_{4}(\text { fsaaep })_{4}\right] / \mathrm{C}, \mathrm{Pt}-\left[\mathrm{Pr}_{2} \mathrm{Cu}_{4}(\text { fsaaep })_{4}\right] / \mathrm{C}$, and $\mathrm{Pt}-\left[\mathrm{Gd}_{2} \mathrm{Cu}_{4}(\text { fsaaep })_{4}\right] / \mathrm{C}$, respectively. Seeing the current ratio for $1 \% \mathrm{CO} / \mathrm{H}_{2}$ as compared to $\mathrm{H}_{2}$, the catalyst $\mathrm{Pt}-\left[\mathrm{Lu}_{2} \mathrm{Cu}_{4}(\text { fsaaep })_{4}\right] / \mathrm{C}$ showed a high $\mathrm{CO}$ tolerance under $1 \%$ level of $\mathrm{CO}$ in $\mathrm{H}_{2}$ saturated in $0.1 \mathrm{~mol} \mathrm{dm}^{-3} \mathrm{HClO}_{4}$. The catalytic activity of a commercial $\mathrm{Pt}-\mathrm{Ru} / \mathrm{C}$ (Johnson Matthey) used for comparison was also maintained under $1 \% \quad \mathrm{CO} / \mathrm{H}_{2}$. However, the catalytic activity of $\mathrm{Pt}-\left[\mathrm{Pr}_{2} \mathrm{Cu}_{4}(\text { fsaaep })_{4}\right] / \mathrm{C}$ and $\left.\mathrm{Pt}-\left[\mathrm{Gd}_{2} \mathrm{Cu}_{4} \text { (fsaaep }\right)_{4}\right] / \mathrm{C}$ decreased below $35 \%$ under $1 \% \mathrm{CO} / \mathrm{H}_{2}$.

Figure 3 depicts the variation of the hydrogen oxidation current with time, which was conducted to evaluate $\mathrm{CO}$ tolerance with time. The current was measured at $1 \% \mathrm{CO}$ in $\mathrm{H}_{2}$ with $\mathrm{RDE}$ at $0.1 \mathrm{~V}$ vs RHE for a period of $600 \mathrm{~s}$, after keeping the potential at $0.8 \mathrm{~V}$ vs RHE for $60 \mathrm{~s}$. The hydrogen oxidation currents of $\mathrm{Pt}-\left[\mathrm{Lu}_{2} \mathrm{Cu}_{4}(\text { fsaaep })_{4}\right] / \mathrm{C}$ and $\mathrm{Pt}-\mathrm{Ru} / \mathrm{C}$ were maintained after duration for $600 \mathrm{~s}$. In constant, the hydrogen oxidation currents of $\mathrm{Pt}-\left[\mathrm{Pr}_{2} \mathrm{Cu}_{4}(\text { fsaaep })_{4}\right] / \mathrm{C}$ and $\mathrm{Pt}-\left[\mathrm{Gd}_{2} \mathrm{Cu}_{4}(\text { fsaaep })_{4}\right] / \mathrm{C}$ declined immediately after $1 \% \quad \mathrm{CO} / \mathrm{H}_{2}$ inlet. From these behaviors, $\left.\mathrm{Pt}-\left[\mathrm{Lu}_{2} \mathrm{Cu}_{4} \text { (fsaaep }\right)_{4}\right] / \mathrm{C}$ was expected to be a good anode catalyst for PEFC because of high $\mathrm{CO}$ tolerance. The dependence of $\mathrm{CO}$ tolerance on lanthanoid metals suggests that the metal site would work for $\mathrm{CO}$ adsorption, and this tendency is strongly affected by the metal element.

Figure 4 shows the $\mathrm{CO}$ oxidation peaks observed during the anodic potential sweep of the stripping tests in $0.1 \mathrm{~mol} \mathrm{dm}{ }^{-3} \mathrm{HClO}_{4}$. $\mathrm{CO}$ stripping was performed after the linear sweep voltammetry experiment for $\mathrm{CO}$ tolerance, switching the gas from $1 \% \mathrm{CO} / \mathrm{H}_{2}$ to $\mathrm{N}_{2}$. Preadsorbed $\mathrm{CO}$ is oxidized during the first anode potential sweep, and repeated scanning did not reveal any more peaks.

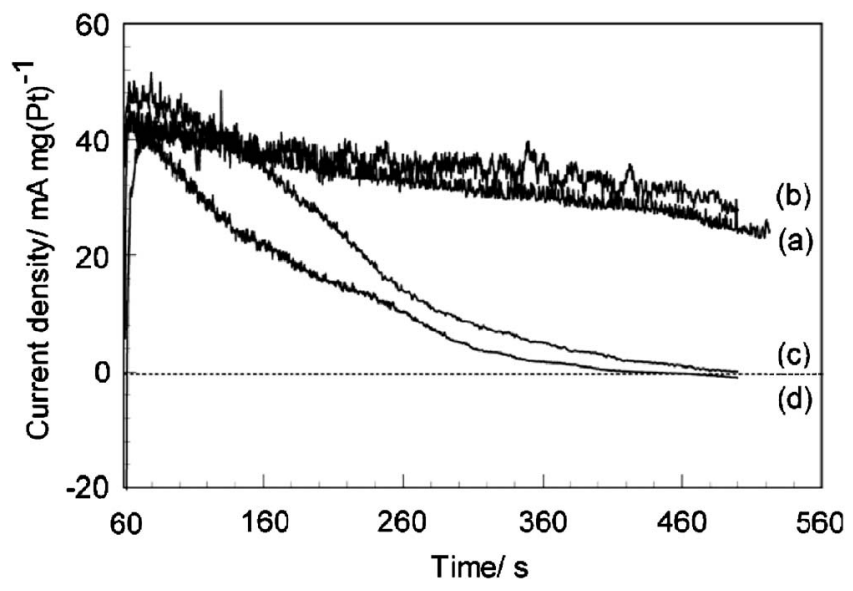

Figure 3. Time variation of HOR current density on RDE with various catalysts measured in $0.1 \mathrm{~mol} \mathrm{dm}{ }^{-3} \mathrm{HClO}_{4}$, after keeping the potential for $60 \mathrm{~s}$ at $0.8 \mathrm{~V}$ vs RHE and then at $0.1 \mathrm{~V}$ vs RHE for $600 \mathrm{~s}$ : (a) $\mathrm{Pt}-\mathrm{Ru} / \mathrm{C}$, (b) $\mathrm{Pt}-\left[\mathrm{Lu}_{2} \mathrm{Cu}_{4}(\text { fsaaep })_{4}\right] / \mathrm{C}$, (c) $\mathrm{Pt}-\left[\mathrm{Pr}_{2} \mathrm{Cu}_{4}(\text { fsaaep })_{4}\right] / \mathrm{C}$, and (d) Pt$\left[\mathrm{Gd}_{2} \mathrm{Cu}_{4}(\text { fsaaep })_{4}\right] / \mathrm{C}$.

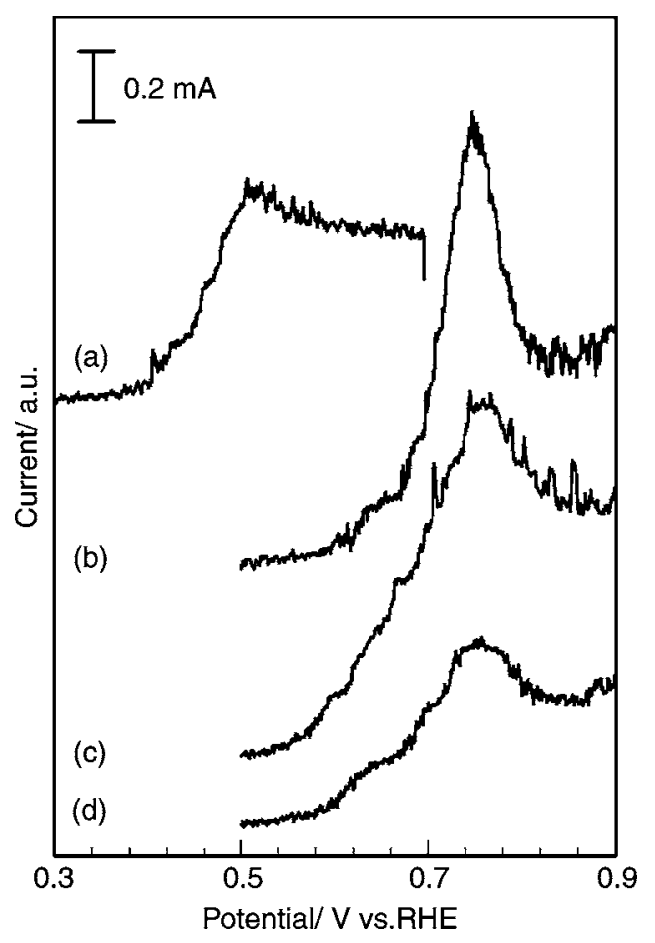

Figure 4. $\mathrm{CO}$ stripping voltammetry after keeping the potential at $0.1 \mathrm{~V}$ RHE for $10 \mathrm{~min}$ in hydrogen gas containing $1 \% \mathrm{CO}$ : (a) $\mathrm{Pt}-\mathrm{Ru} / \mathrm{C}$, (b) $\mathrm{Pt}-\left[\mathrm{Lu}_{2} \mathrm{Cu}_{4}(\text { fsaaep })_{4}\right] / \mathrm{C}$, (c) $\mathrm{Pt}-\left[\mathrm{Pr}_{2} \mathrm{Cu}_{4}(\text { fsaaep })_{4}\right] / \mathrm{C}$, and (d) $\mathrm{Pt}$ $\left[\mathrm{Gd}_{2} \mathrm{Cu}_{4}(\text { fsaaep })_{4}\right] / \mathrm{C}$.

The $\mathrm{CO}$ oxidation peaks of $\mathrm{Pt}-\left[\mathrm{Lu}_{2} \mathrm{Cu}_{4}(\text { fsaaep })_{4}\right] / \mathrm{C}$, Pt$\left[\mathrm{Pr}_{2} \mathrm{Cu}_{4}(\text { fsaaep })_{4}\right] / \mathrm{C}$, and $\mathrm{Pt}-\left[\mathrm{Gd}_{2} \mathrm{Cu}_{4}(\text { fsaaep })_{4}\right] / \mathrm{C}$ appeared at $0.76 \mathrm{~V}$ vs RHE, which agreed with the $\mathrm{CO}$ oxidation peak of $\mathrm{Pt} / \mathrm{C} .{ }^{13}$ The $\mathrm{CO}$ oxidation peak of $\mathrm{Pt}-\mathrm{Ru} / \mathrm{C}$ was observed at a much lower potential $(0.49 \mathrm{~V}$ vs RHE), indicating that organic-metal-complexbased catalysts may exhibit different behavior during $\mathrm{H}_{2}(\mathrm{CO})$ oxidation in comparison with traditional $\mathrm{Pt}-\mathrm{Ru}$ catalysts. Against the expectation, the height of $\mathrm{CO}$ oxidation peaks was in the order: $\mathrm{Pt}-\left[\mathrm{Lu}_{2} \mathrm{Cu}_{4}(\text { fsaaep })_{4}\right] / \mathrm{C}>\mathrm{Pt}-\left[\mathrm{Pr}_{2} \mathrm{Cu}_{4}(\text { fsaaep })_{4}\right] / \mathrm{C}>\mathrm{Pt}-\left[\mathrm{Gd}_{2} \mathrm{Cu}_{4}\right.$ (fsaaep) $\left.{ }_{4}\right] / \mathrm{C}$, which indicates that the amount (and ease) of $\mathrm{CO}$ adsorption on the catalysts is in this order. Seeing the CO stripping potential, Pt would work as the site of $\mathrm{CO}$ adsorption, but the lanthanoid metal site would also participate in $\mathrm{CO}$ adsorption.

$\mathrm{CO}$ tolerance tests for the anode catalysts were carried out in a half-cell at $70^{\circ} \mathrm{C}$, consisting of a half-MEA with a Nafion 115 membrane in $\mathrm{H}_{2}$ gas and in $\mathrm{H}_{2}$ with various concentrations of $\mathrm{CO}$ at the same $\mathrm{Pt}$ amount. Figure 5 shows the polarization curves of hydrogen oxidation for $\mathrm{Pt}-\mathrm{Ru} / \mathrm{C}$ and $\mathrm{Pt}-\left[\mathrm{Lu}_{2} \mathrm{Cu}_{4}(\text { fsaaep })_{4}\right] / \mathrm{C}$ in $\mathrm{H}_{2}$ with various concentrations of $\mathrm{CO}$. In pure $\mathrm{H}_{2}$, the catalytic activities of both electrode catalysts were not much different. The catalytic activity of $\mathrm{Pt}-\left[\mathrm{Lu}_{2} \mathrm{Cu}_{4}(\text { fsaaep })_{4}\right] / \mathrm{C}$ was maintained above $50 \%$ under $100 \mathrm{ppm}$ level CO. In content, the catalytic activity of $\mathrm{Pt}-\mathrm{Ru} / \mathrm{C}$ decreased with increasing $\mathrm{CO}$ concentration.

Table II summarizes the hydrogen oxidation currents in a halfcell, measured on various electrocatalysts in $\mathrm{H}_{2}$ gas and in $\mathrm{H}_{2}$ with various concentrations of $\mathrm{CO}$ at the same $\mathrm{Pt}$ amount. The mass activities in $\mathrm{H}_{2}$ gas were $3.78,3.38,2.98$, and $3.61 \mathrm{~A} \mathrm{mg}(\mathrm{Pt})^{-1}$ for $\mathrm{Pt}-\mathrm{Ru} / \mathrm{C}, \mathrm{Pt}-\left[\mathrm{Lu}_{2} \mathrm{Cu}_{4}(\text { fsaaep })_{4}\right] / \mathrm{C}, \mathrm{Pt}-\left[\mathrm{Pr}_{2} \mathrm{Cu}_{4}(\text { fsaaep })_{4}\right] / \mathrm{C}$, and $\mathrm{Pt}-\left[\mathrm{Gd}_{2} \mathrm{Cu}_{4}(\text { fsaaep })_{4}\right] / \mathrm{C}$, respectively. For 10 and $100 \mathrm{ppm} \mathrm{CO}$, the retention of the current from the pure $\mathrm{H}_{2}$ to $\mathrm{CO}$-containing $\mathrm{H}_{2}$ was 84 and 20, 77 and 46, 88 and 32 , and 86 and $32 \%$ for $\mathrm{Pt}-\mathrm{Ru} / \mathrm{C}, \mathrm{Pt}-\left[\mathrm{Lu}_{2} \mathrm{Cu}_{4}(\text { fsaaep })_{4}\right] / \mathrm{C}, \mathrm{Pt}-\left[\mathrm{Pr}_{2} \mathrm{Cu}_{4}(\text { fsaaep })_{4}\right] / \mathrm{C}$, and Pt- $\left[\mathrm{Gd}_{2} \mathrm{Cu}_{4}\left(\right.\right.$ fsaaep $\left._{4}\right] / \mathrm{C}$, respectively. Comparing Table II with Table I, it is roughly seen that the CO tolerance performance accords 

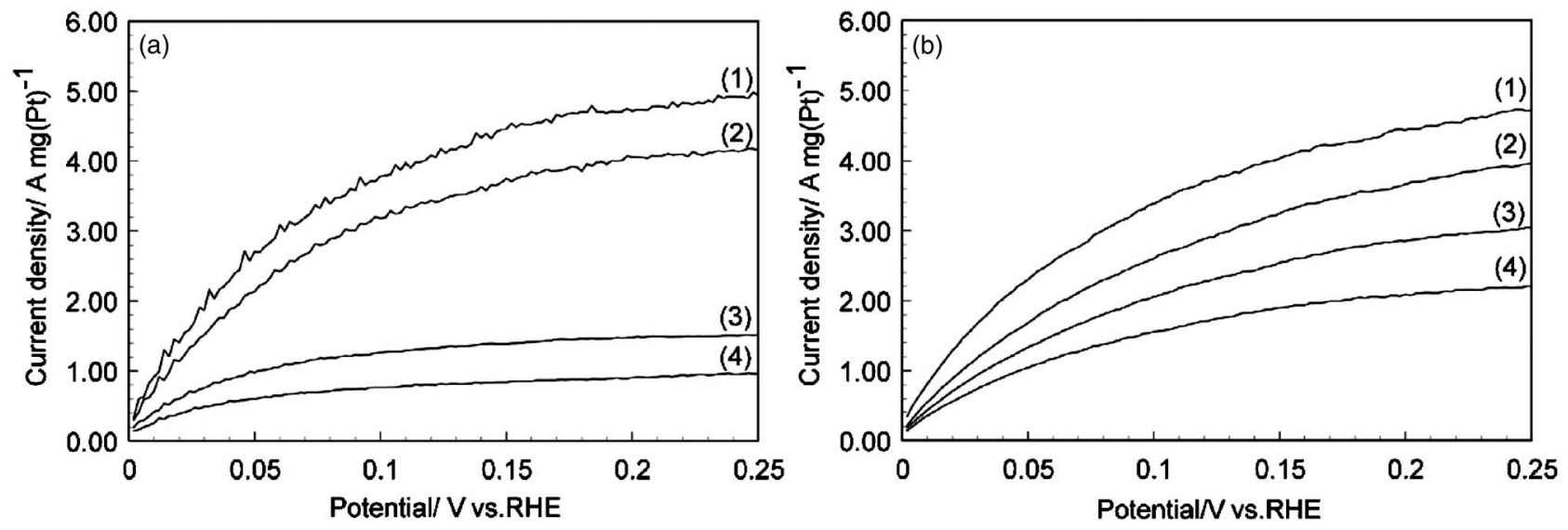

Figure 5. Current-potential curves under various amounts of $\mathrm{CO}$ for (a) $\mathrm{Pt}-\mathrm{Ru} / \mathrm{C}$ and (b) $\mathrm{Pt}-\left[\mathrm{Lu}_{2} \mathrm{Cu}_{4}(\mathrm{fsaaep})_{4}\right] / \mathrm{C}$ : (1) pure $\mathrm{H}_{2}$, (2) $10 \mathrm{ppm} \mathrm{CO} / \mathrm{H}_{2}$, (3) $50 \mathrm{ppm}$ $\mathrm{CO} / \mathrm{H}_{2}$, and (4) $100 \mathrm{ppm} \mathrm{CO} / \mathrm{H}_{2}$. Table II. Comparison of $\mathrm{H}_{2}$ oxidation current at $0.1 \mathrm{~V}$ vs RHE on various electrocatalysts, measured in a half-cell at $70^{\circ} \mathrm{C}$ with $\mathrm{H}_{2}$ anode gas
containing various amounts of $\mathrm{CO}$.

\begin{tabular}{lccrr} 
& \multicolumn{5}{c}{ Mass activity $\left[\mathrm{A} \mathrm{mg}\left(\mathrm{Pt}^{-1}\right)\right] /$ current ratio $(\%)$} \\
\cline { 2 - 5 } Catalysts & \multicolumn{1}{c}{$\mathrm{H}_{2}$} & $10 \mathrm{ppm} \mathrm{CO} / \mathrm{H}_{2}$ & $50 \mathrm{ppm} \mathrm{CO} / \mathrm{H}_{2}$ & $100 \mathrm{ppm} \mathrm{CO} / \mathrm{H}_{2}$ \\
\hline $20 \mathrm{wt} \% \mathrm{Pt}-10 \mathrm{wt} \% \mathrm{Ru} / \mathrm{C}$ & $3.78(100)$ & $3.18(84)$ & $1.27(34)$ & $0.77(20)$ \\
$20 \mathrm{wt} \% \mathrm{Pt}-\left[\mathrm{Lu}_{2} \mathrm{Cu}_{4}(\mathrm{fsaaep})_{4}\right] / \mathrm{C}$ & $3.38(100)$ & $2.60(77)$ & $2.06(64)$ & $1.55(46)$ \\
$20 \mathrm{wt} \% \mathrm{Pt}-\left[\mathrm{Pr}_{2} \mathrm{Cu}_{4}(\mathrm{fsaaep})_{4}\right] / \mathrm{C}$ & $2.98(100)$ & $2.61(88)$ & $1.47(49)$ & $0.94(32)$ \\
$20 \mathrm{wt} \% \mathrm{Pt}-\left[\mathrm{Gd}_{2} \mathrm{Cu}_{4}(\text { fsaaep })_{4}\right] / \mathrm{C}$ & $3.61(100)$ & $3.10(86)$ & $2.27(63)$ & $1.17(32)$
\end{tabular}
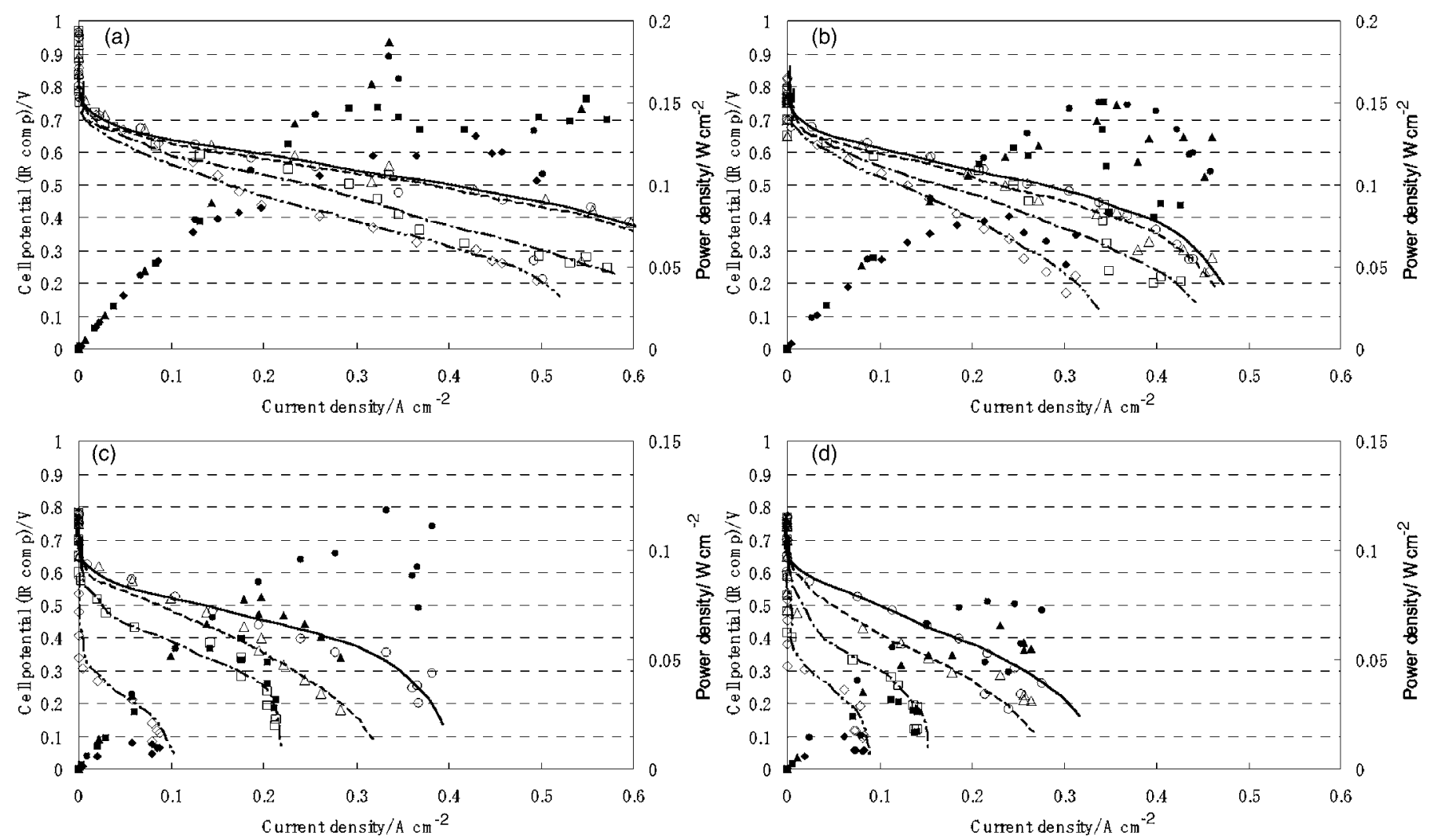

Figure 6. Polarization curves and power density-current density curves of (a) Pt-Ru/C, (b) Pt- $\left[\mathrm{Lu}_{2} \mathrm{Cu}_{4}(\mathrm{fsaaep})_{4}\right] / \mathrm{C},(\mathrm{c}) \mathrm{Pt}-\left[\mathrm{Pr}_{2} \mathrm{Cu}_{4}(\mathrm{fsaaep})_{4}\right] / \mathrm{C}$, and $(\mathrm{d})$ Pt- $\left[\mathrm{Gd}_{2} \mathrm{Cu}_{4}(\text { fsaaep })_{4}\right] / \mathrm{C}$ measured with a PEFC single cell. Anode gas: $\mathrm{H}_{2}(\bigcirc), \mathrm{H}_{2}+10$ ppm CO $(\triangle), \mathrm{H}_{2}+50 \mathrm{ppm} \operatorname{CO}(\square)$, and $\mathrm{H}_{2}+100 \mathrm{ppm} \mathrm{CO}(\diamond)$.

well between two kinds of $\mathrm{HOR}$ experiments, and $1 \% \mathrm{CO} / \mathrm{H}_{2}$ in $0.1 \mathrm{~mol} \mathrm{dm}^{-3} \mathrm{HClO}_{4}$ for RDE corresponds with $\mathrm{CO}$ in the $\mathrm{H}_{2}$ gas phase of a half-cell somewhere between 10 and $50 \mathrm{ppm}$. It is re- markable that the performance of electrocatalysts based on Pt and the organic metal complex revealed high activity for $\mathrm{H}_{2}$ oxidation in the presence of $\mathrm{CO}$ as compared to $\mathrm{Pt}-\mathrm{Ru} / \mathrm{C}$. 
Polarization curves measured in single fuel cells are illustrated in Fig. 6. In single-cell measurements, the best polarization behavior and $\mathrm{CO}$ tolerance were observed on $\mathrm{Pt}-\mathrm{Ru} / \mathrm{C}$, and the performances for $\mathrm{Pt}-\left[\mathrm{Ln}_{2} \mathrm{Cu}_{4}(\text { fsaaep })_{4}\right] / \mathrm{C}$ declined especially with $\mathrm{Ln}=\mathrm{Pr}$ and $\mathrm{Gd}$, although $\left.\mathrm{Pt}-\left[\mathrm{Lu}_{2} \mathrm{Cu}_{4} \text { (fsaeep) }\right)_{4}\right] / \mathrm{C}$ showed good $\mathrm{CO}$ tolerance. The failure of good polarization performance in pure $\mathrm{H}_{2}$ indicates the problems of the catalyst ink and MEA fabrication for the complex catalysts, as experienced with other organic metal complex catalysts. ${ }^{10,11}$ This weak point is being further addressed now, and researches are in progress to improve the contact of the catalystmembrane interface.

\section{Conclusions}

A unique structure of $\mathrm{Pt}-\left[\mathrm{Ln}_{2} \mathrm{Cu}_{4}(\text { fsaaep })_{4}\right] / \mathrm{C}(\mathrm{Ln}=\mathrm{Lu}, \mathrm{Pr}, \mathrm{Gd})$ (Fig. 1) proved to make a good $\mathrm{CO}$ adsorption site in the metal center, and this resulted in good $\mathrm{CO}$ tolerance when co-catalyzed with Pt. The concept of composite catalysts that contains organic metal complexes as co-catalysts with $\mathrm{Pt}$, with a working hypothesis where the co-catalyst mitigates $\mathrm{CO}$ poisoning on $\mathrm{Pt}$, appears to be successful.

Future work needs to improve the performance of these complex catalysts by overcoming the weak point that such composites made from the metal (Pt) and organic substances (metal complex) deteriorate the mixing capability of the catalyst ink solutions.
National Institute of Advanced Industrial Science and Technology assisted in meeting the publication costs of this article.

\section{References}

1. M. A. J. Cropper, S. Geiger, and D. M. Jollie, J. Power Sources, 131, 57 (2004) 2. T. J. Schmidt, M. Noeske, H. A. Gasteiger, R. J. Behm, P. Britz, W. Brijoux, and H. Bonnemann, Langmuir, 13, 2561 (1997).

3. J. Divisek, H. F. Oetjen, V. Peinecke, V. M. Schmidt, and U. Stimming, Electrochim. Acta, 43, 3811 (1998).

4. S. Mukerjee, S. J. Lee, E. A. Ticianelli, J. McBreen, B. N. Grgur, N. M. Markovic, P. N. Ross, J. R. Giallombardo, and E. S. De Castro, Electrochem. Solid-State Lett., 2, 12 (1999).

5. A. Kabbabi, R. Faure, R. Durand, B. Beden, F. Hahn, J. M. Leger, and C. Lamy, J. Electroanal. Chem., 444, 41 (1998).

6. H. A. Gasteiger, N. M. Markovic, and P. N. Ross, Jr., J. Phys. Chem., 99, 8290 (1995).

7. M. S. Wilson, F. H. Garzon, K. E. Sickafus, and S. Gottesfeld, J. Electrochem. Soc., 140, 2872 (1993)

8. H. Yano, C. Ono, H. Shiroishi, and T. Okada, Chem. Commun. (Cambridge), 2005 , 1212

9. H. Yano, C. Ono, H. Shiroishi, M. Saito, Y. Uchimoto, and T. Okada, Chem Mater, 18, 4505 (2006).

10. T. Okada, J. Qiao, T. Kahara, and C. Ono, Electrochemistry (Tokyo, Jpn.), 75, 169 (2007)

11. T. Okada, H. Yano, and C. Ono, J. New Mater. Electrochem Syst, 10, 129 (2007).

12. M. Andruh, I. Ramada, E. Codjovi, O. Guillou, O. Kahn, and J. C. Trombe, J. Am. Chem. Soc., 115, 1822 (1993).

13. T. J. Schmidt, H. A. Gasteiger, G. D. Stab, P. M. Urban, D. M. Kolb, and R. J. Behm, J. Electrochem. Soc., 145, 2354 (1998). 